Document downloaded from:

http://hdl.handle.net/10251/178175

This paper must be cited as:

Moussa, S.; Concepción Heydorn, P.; Arribas Viana, MDLD.; Martinez Feliu, A. (2018). Nature of Active Nickel Sites and Initiation Mechanism for Ethylene Oligomerization on Heterogeneous Ni-beta Catalysts. ACS Catalysis. 8(5):3903-3912.

https://doi.org/10.1021/acscatal.7b03970

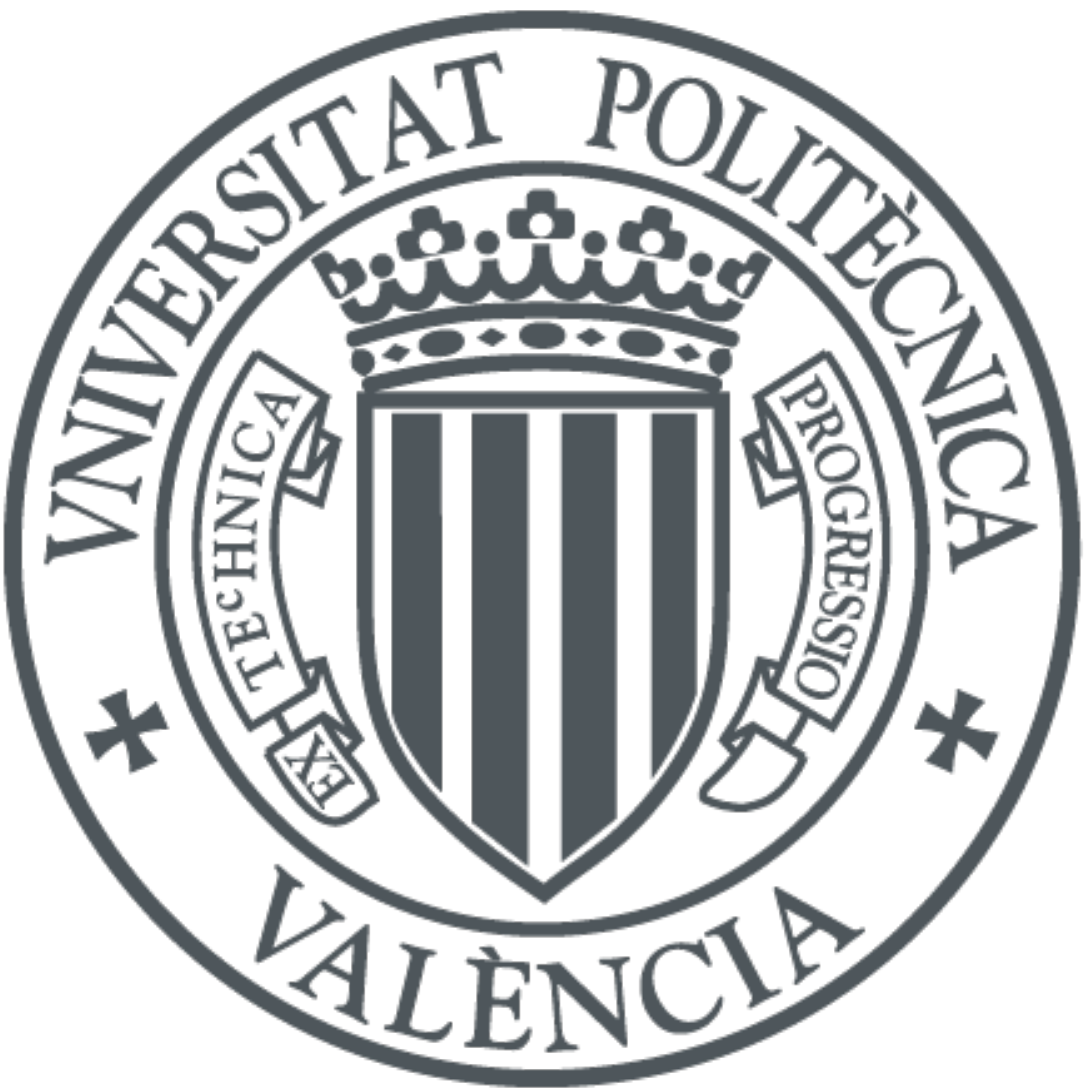

The final publication is available at

https://doi.org/10.1021/acscatal.7b03970

Copyright American Chemical Society

Additional Information 


\title{
Nature of active nickel sites and initiation mechanism for ethylene oligomerization on heterogeneous $\mathrm{Ni}$-beta catalysts
}

\author{
Sara Moussa, Patricia Concepción, María A. Arribas, and Agustín Martínez* \\ Instituto de Tecnología Química, Universitat Politècnica de València - Consejo Superior de Investigaciones Científicas \\ (UPV-CSIC), Avda. de los Naranjos s/n, 46022 Valencia, Spain
}

\begin{abstract}
Higher olefins produced via ethylene oligomerization are versatile commodity chemicals serving a vast range of industries with large global economic impact. Nickel-aluminosilicates are promising candidates to replace the homogeneous catalysts employed in industrial ethylene oligomerization processes. Current poor understanding of the true nature of the active nickel centers and the nickel-mediated oligomerization mechanism in these materials, however, hampers the rational design of improved catalysts. Here we applied in situ time- and temperature-resolved FTIR spectroscopy with simultaneous MS analysis of products to disentangle these fundamental issues using nanocrystalline $\mathrm{Ni}$-beta zeolite as catalyst. We elucidate that isolated $\mathrm{Ni}^{2+}$ cations grafted on acidic silanols are the most likely active species in the working catalysts rather than the generally accepted ion-exchanged nickel cations. Based on our results, a plausible initiation mechanism involving a nickel-vinyl-hydride intermediate from which chain propagation proceeds similar to the Cossee-Arlman pathway is proposed.
\end{abstract}

KEYWORDS: ethylene oligomerization, nickel-beta catalyst, in situ FTIR spectroscopy, active nickel sites, reaction mechanism

\section{INTRODUCTION}

Higher olefins produced through the oligomerization of ethylene are key intermediates in the chemical industry for the manufacture of valuable products such as plasticizers, synthetic lubricants, additives, and surfactants ${ }^{1-4}$. A major application of ethylene oligomers is their use as co-monomers in the production of linear low-density polyethylene (LLDPE), a flexible polymer with an expanding market ${ }^{3-5}$. Although nowadays ethylene is primarily produced by steam cracking of oilderived naphtha fractions, the projected increasing capacity of ethane-based crackers using abundant low-cost ethane from shale gas will expectedly increase the availability of ethylene at a more competitive cost making its catalytic conversion to value-added chemicals and clean fuels even more attractive ${ }^{6-7}$. Nowadays, the oligomerization of ethylene is commercially carried out in homogeneous phase using suitable organic solvents and transition metal complexes ( $\mathrm{Ti}, \mathrm{Zr}, \mathrm{V}, \mathrm{Cr}, \mathrm{Ni}$, etc.) as catalysts assisted by alkyl aluminum compounds (e.g. methylaluminoxane or MAO) acting as co-catalysts or initiators ${ }^{1,5}$. The function of the co-catalyst in the homogeneous systems is to alkylate the metal center providing the first metal-carbon bond on which the oligomerization can then proceed through the classical Cossee-Arlman pathway (Scheme 1). According to this mechanism ${ }^{8-9}$, the alkyl chain grows by coordination of ethylene to a vacant site of the metal center and subsequent migratory insertion into the preexistent metalcarbon bond. Then, desorption of the $\alpha$-olefin product may take place via $\beta$-hydride elimination or $\beta$-hydride transfer (not shown in the scheme) restoring the Cossee-Arlman site as, respectively, metal-H or metal-ethene- $\mathrm{H}$.
Scheme 1. Cossee-Arlman mechanism proposed for the oligomerization of ethylene on homogeneous catalysts.

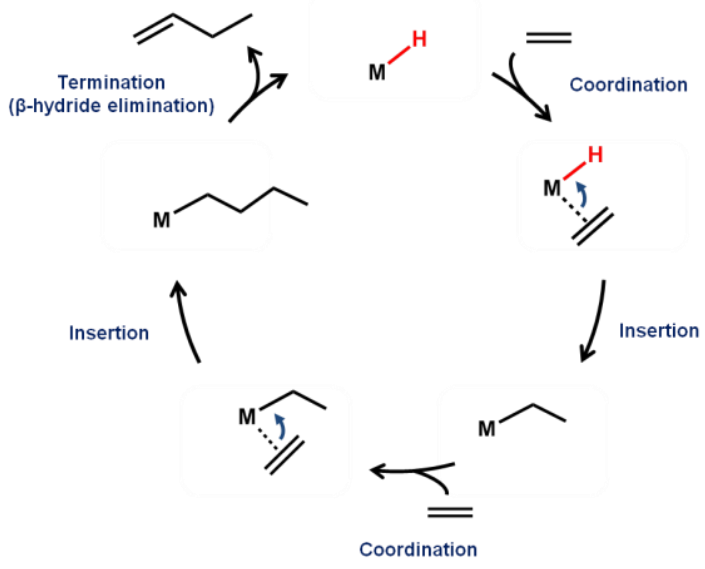

The environmental and technical issues associated to the homogeneous processes encourage the development of an alternative, more sustainable technology for ethylene oligomerization relying on robust heterogeneous catalysts. In this regard, dual-functional materials comprised of nickel ions dispersed on acidic porous aluminosilicates such as mesoporous amorphous silica-alumina ${ }^{10-14}$, Al-doped ordered mesoporous silicas (e.g. Al-MCM-41, Al-SBA-15, and related materials) ${ }^{15-20}$, and zeolites ${ }^{21-25}$ are the most prospective solid catalysts so far investigated for this reaction. However, catalysts based on Ni dispersed on purely microporous zeolites such as 
$\mathrm{X}^{21}, \mathrm{Y}^{22}$, and MCM-22 23 typically experience a fast deactivation due to the accumulation of heavy oligomers within the channels and cages. Differently, we recently reported a nanocrystalline Ni-beta zeolite that exhibits a stable activity in ethylene oligomerization at industrially-relevant conditions ${ }^{24}$. This was ascribed to the lack of cages in the beta structure and to the enhanced transport rate of the bulky oligomers in the nanosized crystallites of Ni-beta catalysts ${ }^{24}$.

On these heterogeneous Ni-based catalysts, ethylene is first activated and oligomerized on the nickel sites yielding mainly linear $\mathrm{C}_{4}-\mathrm{C}_{8}$ olefins that subsequently react on the Brønsted acid sites of the aluminosilicate carrier via classical carbocation chemistry increasing the average chain length and degree of branching of the final products. Tuning the balance between these two catalytic functions at the catalyst synthesis stage endows these materials with the possibility to alter, to a certain extent, the product slate to suit market requirements.

The detailed knowledge of the structure of active sites and the reaction mechanism in heterogeneous catalysis is essential to the rational design of improved catalytic materials. In the case of ethylene oligomerization catalyzed by nickelaluminosilicates, both the nature of the active nickel species and the nickel-mediated initiation-oligomerization mechanism are still subjects of controversy. As for the active sites, isolated ion-exchanged nickel cations, i.e. those replacing $\mathrm{H}^{+}$in bridged $\mathrm{Si}-\mathrm{OH}-\mathrm{Al}$ groups of the acidic aluminosilicate carrier, are widely assumed to be the active species $^{2,13,15,19,24-26}$, although their oxidation state has been extensively debated. Thus, even though in most previous studies monovalent nickel ions were postulated as the most likely active sites ${ }^{16,21,27-32}$,

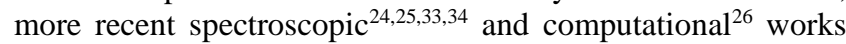
advocate for divalent nickel as the active nickel species. Moreover, for Ni-aluminosilicates with low density of framework $\mathrm{Al}$ sites (i.e. high $\mathrm{Si} / \mathrm{Al}$ ratio), where the presence of two nearby $\mathrm{H}^{+}$seems unlikely, isolated $(\mathrm{Ni}-\mathrm{OH})^{+}$moieties grafted onto exchange sites have also been recently proposed as catalytically active species $^{35}$. Whatever their oxidation state, the assignment of ion-exchanged nickel ions as the unique active sites seems questionable to us at the view of our recent results reporting a mismatch between their concentration and the activity for ethylene oligomerization in different $\mathrm{Ni}$ aluminosilicates compared at identical reaction conditions ${ }^{33}$. Moreover, a general consensus about the mechanism by which ethylene is activated and oligomerized on the nickel-based heterogeneous catalysts without requiring the intervention of co-catalysts has not yet been reached and distinct conflicting views are found in the recent literature. In this respect, the Cossee-Arlman pathway was indicated as the most probable mechanism operating in different heterogeneous nickel-based catalysts based on kinetic studies ${ }^{13,25,36}$, isotopic labeling experiments $^{37}$, and Density Functional Theory (DFT) calculations $^{26,37}$. A central question in the Cossee-Arlman pathway over Ni-aluminosilicates is how the required $\mathrm{Ni}-\mathrm{H}$ (or $\mathrm{Ni}$ ethene-H upon insertion of ethylene into the $\mathrm{Ni}-\mathrm{H}$ bond) species, the so-called Cossee-Arlman centers, are generated upon interaction of ethylene with the nickel sites. In this regard, several possible routes leading to a Cossee-Arlman site have been suggested, among which the reaction between a neutral nickel atom ${ }^{26}$ or a nickel cation at an ion exchange position ${ }^{13}$ with a Brønsted acid site of the acidic carrier, and through a pathway initiated by proton-transfer encompassing the creation of a new Brønsted acid center and the desorption of butadiene $^{26}$ (see Scheme S1 for details), are worth of mention. An additional possible route for the formation of Cossee-Arlman centers involving the reaction of ethylene with $(\mathrm{Ni}-\mathrm{OH})^{+}$species, lately proposed as active sites in high $\mathrm{Si} / \mathrm{Al}$ ratio $\mathrm{Ni}-\mathrm{Al}$ MCM-41 catalysts ${ }^{35}$, has also been suggested on the basis of DFT calculations ${ }^{26}$. However, by analogy with similar $(\mathrm{Cu}-$ $\mathrm{OH})^{+}$species present in $\mathrm{Cu}$-exchanged zeolites ${ }^{38}$, the authors questioned whether the $(\mathrm{Ni}-\mathrm{OH})^{+}$centers would persist after the standard high temperature catalyst pretreatment under inert atmosphere or decompose to $\mathrm{Ni}^{+}$via "self-reduction" upon losing the $\mathrm{OH}$ ligand $^{26}$. Nevertheless, none of the suggested pathways resulting in $\mathrm{Ni}-\mathrm{H}$ sites were conclusive or confirmed by direct experimental observations. Alternatively, an oligomerization mechanism initiated by the oxidative coupling of two ethylene molecules coordinated at an isolated nickel ion involving the formation of metallacycles as intermediates has also been proposed ${ }^{15}$ (Scheme S2).

Definitively solving these fundamental questions will be crucial to devise suitable strategies for designing more efficient heterogeneous nickel-based catalysts with better chance for industrial implementation. To this aim, in this work we first combined catalytic experiments with online analysis of products by mass spectrometry (MS) and in situ FTIR-CO spectroscopy with unprecedented high temporal resolution in the very early stages of the reaction to uncover the structure of the active $\mathrm{Ni}$ sites during the oligomerization of ethylene on nanocrystalline Ni-beta catalysts ${ }^{24}$. Next, we performed temperature-resolved FTIR under flowing ethylene while simultaneously monitoring the desorbed gas phase products by online MS to derive, for the first time relying on experimentally detected intermediates, a plausible mechanism for the initial activation and oligomerization of ethylene on the active nickel sites.

\section{EXPERIMENTAL SECTION}

Preparation of Ni-beta catalysts. Ni-beta catalysts with nickel loadings ranging from 1 to $10 \mathrm{wt} \%$ were prepared by incipient wetness impregnation of a commercially available nanocrystalline H-beta zeolite (CP811, Zeolyst, atomic Si/Al ratio of 13 , crystallite size $20-25 \mathrm{~nm}$ ) with an aqueous solution containing the required amount of $\mathrm{Ni}\left(\mathrm{NO}_{3}\right)_{2} \cdot 6 \mathrm{H}_{2} \mathrm{O}$ precursor (Sigma-Aldrich, $>97 \%$ purity) to achieve the targeted Ni loading. After impregnation the samples were dried at $100{ }^{\circ} \mathrm{C}$ overnight and subsequently calcined under flowing air at 550 ${ }^{\circ} \mathrm{C}$ for $3 \mathrm{~h}$ using a heating rate of $1{ }^{\circ} \mathrm{C} / \mathrm{min}$. The air-calcined materials are labeled as $x$ Ni-beta, where $x$ stands for the nominal nickel loading in wt $\%$. The main physicochemical properties of $x \mathrm{Ni}$-beta catalysts were reported elsewhere ${ }^{24}$.

Catalytic activity. Ethylene oligomerization experiments were carried out at ambient pressure under differential conversions conditions $(<2 \%)$ in a continuous glass fixed bed reactor with very low dead volume operated at $120{ }^{\circ} \mathrm{C}, 0.95$ bar of ethylene (balanced by Ar) and space velocity of $33 \mathrm{~h}^{-1}$. These conditions were purposely applied so as to minimize the contribution of acid catalysis and, thus, the formation of long chain products. The reactor was loaded with ca. $100 \mathrm{mg}$ of catalyst with a pellet size of $0.2-0.4 \mathrm{~mm}$ diluted with $\mathrm{SiC}$ granules $(0.6-0.8 \mathrm{~mm}$ size) so as to obtain a constant bed volume of $1 \mathrm{~cm}^{3}$. Prior to the catalytic experiments, the catalyst was pretreated in situ under flowing $\mathrm{N}_{2}\left(20 \mathrm{~cm}^{3} / \mathrm{min}\right)$ at atmospheric pressure and $300{ }^{\circ} \mathrm{C}$ for $3 \mathrm{~h}$. Afterwards, the reactor was cooled down to the reaction temperature of $120{ }^{\circ} \mathrm{C}$ under $\mathrm{N}_{2}$ flow. Then, the $\mathrm{N}_{2}$ flow was stopped and the required flow 
of the reactant gas mixture comprising $95 \mathrm{~mol} \%$ ethylene and $5 \mathrm{~mol} \% \mathrm{Ar}$ (used as internal standard for GC analyses) was established through the reactor and kept flowing for a period of ca. 100 min on stream once the catalyst reached a pseudosteady state behavior. Reaction products were continuously monitored by online MS with a Balzer (QMG 220M1, Omnistar) mass spectrometer running in the multi-ion monitoring mode (MID) using preselected $\mathrm{m} / \mathrm{z}$ values (Table $\mathrm{S} 1$ ). Mass spectral analyses were performed in a qualitative mode due to the high complexity of the mass fragmentations hampering a quantitative assessment of product concentrations. In order to obtain quantitative catalytic data, representative samples of the gaseous products were collected at specific reaction times and analyzed offline in a Bruker 450 gas chromatograph equipped with a capillary column (BR-1 FS, $50 \mathrm{~m}$ x $0.25 \mathrm{~mm} \times 0.5 \mu \mathrm{m}$ ), two packed columns (Hayesep Q, and Molecular Sieve 13 X), and both TCD and FID type detectors.

In situ time-resolved FTIR and FTIR-CO surface titration studies. Infrared spectra were recorded in a Nexus (Thermo) 8700 FTIR spectrometer using a DTGS detector and acquiring at $4 \mathrm{~cm}^{-1}$ resolution. A commercial Aabspec cell, allowing for in situ treatments in controlled atmospheres and spectra acquisition in the temperature range from $-176{ }^{\circ} \mathrm{C}$ to $500{ }^{\circ} \mathrm{C}$, was employed in these experiments. Before spectra acquisition, the calcined $x \mathrm{Ni}$-beta samples were pressed into self-supported wafers of ca. $10 \mathrm{mg} / \mathrm{cm}^{2}$ and thermally treated in situ at $300{ }^{\circ} \mathrm{C}$ for $3 \mathrm{~h}$ in flowing $\mathrm{N}_{2}\left(20 \mathrm{~cm}^{3} / \mathrm{min}\right)$, mimicking the in-reactor pretreatment performed prior the catalytic tests. Afterwards, the temperature in the IR cell was lowered to $120{ }^{\circ} \mathrm{C}$ (the applied reaction temperature), and the gas flow switched from $\mathrm{N}_{2}$ to pure ethylene. Then, the ethylene flow was stopped at the selected time (10 s, $8 \mathrm{~min}, 30 \mathrm{~min}$, and $70 \mathrm{~min})$ and the sample was immediately evacuated to $10^{-1}$ mbar using a rotatory pump and subsequently to $10^{-5}$ mbar using a turbomolecular pump while maintaining the temperature at $120^{\circ} \mathrm{C}$ for $1 \mathrm{~h}$. At this point, the FTIR spectra were acquired in order to study the nature and stability of the adsorbed species. Subsequently, for the FTIR-CO titration of the surface nickel species, the sample was cooled down to $-176{ }^{\circ} \mathrm{C}$ under dynamic vacuum of $10^{-5}$ mbar and $\mathrm{CO}$ dosed at increasing pressures (0.1-2.0 mbar). The FTIR spectrum was recorded following each dose until CO saturation. Deconvolution of the IR spectra was done using the ORIGIN software keeping the FWHM for a given peak constant between samples. For comparative purposes, the IR spectra were normalized by sample overtone area in the 2104-1746 $\mathrm{cm}^{-1}$ frequency range.

XPS measurements. X-ray photoelectron spectroscopy (XPS) measurements were performed on a SPECS spectrometer with a 150 MCD-9 detector and using a non-monochromatic AlK $\alpha$ (1486.6 eV) X-ray source. Spectra were recorded using analyzer pass energy of $30 \mathrm{~V}$, an X-ray power of $100 \mathrm{~W}$ and under an operating pressure of $10^{-9}$ mbar. Spectra treatment was performed using the CASA software. Binding energies (BE) were referenced to $\mathrm{C} 1 \mathrm{~s}$ peak at $284.5 \mathrm{eV}$. XP spectra were recorded both after in situ pretreatment of 5Ni-beta sample in flowing $\mathrm{N}_{2}$ at $300{ }^{\circ} \mathrm{C}$ for $3 \mathrm{~h}$ and after in situ reaction with flowing ethylene $\left(5 \mathrm{~cm}^{3} / \mathrm{min}\right)$ at $120^{\circ} \mathrm{C}$ for $2 \mathrm{~h}$ in a high pressure catalytic cell (HPC) connected to the spectrometer chamber.

In situ temperature-resolved FTIR spectroscopy coupled to online MS analysis of desorbed products. For the mechanistic studies, a homemade FTIR cell allowing in situ treatments in controlled atmospheres and spectra acquisition in the temperature range from $-176{ }^{\circ} \mathrm{C}$ to $500{ }^{\circ} \mathrm{C}$ has been used. A selfsupported wafer (ca. $10 \mathrm{mg} / \mathrm{cm}^{2}$ ) of calcined $5 \mathrm{Ni}$-beta catalyst was introduced in the cell and activated in situ at $300{ }^{\circ} \mathrm{C}$ for 3 $\mathrm{h}$ in flowing $\mathrm{N}_{2}\left(20 \mathrm{~cm}^{3} / \mathrm{min}\right)$, followed by evacuation at the same temperature for $1 \mathrm{~h}$ and cooling down to $-100{ }^{\circ} \mathrm{C}$ under dynamic vacuum. At that temperature ethylene was dosed at a pressure of 1.5 mbar and kept at this pressure until the completion of the experiment. FTIR spectra were then acquired at $100{ }^{\circ} \mathrm{C}$ and at increasing temperatures up to $120^{\circ} \mathrm{C}$ under flowing ethylene. Parallel to the acquisition of FTIR spectra the gaseous products leaving the IR cell were continuously analyzed by online MS in a Balzer (Omnistar) mass spectrometer connected to the IR cell via a fine capillary tube.

\section{RESULTS AND DISCUSSION}

Elucidation of the active nickel sites in Ni-beta catalysts at work. In the first part of the present study we elucidate the structure of the active nickel sites in Ni-beta catalysts at work by confronting the time-evolution of the catalytic activity and surface nickel species at $120^{\circ} \mathrm{C}$ and ambient pressure with an exceptionally high temporal resolution in the very initial reaction stages. Figure 1 depicts the change in intensity with timeon-stream (TOS) of the mass spectral signal of butenes, the predominant products at the applied conditions (selectivity exceeding $80 \%$ ), for the $5 \mathrm{Ni}$-beta catalyst. This catalyst exhibited the highest ethylene oligomerization activity among the series of Ni-beta samples with $\mathrm{Ni}$ contents ranging from ca. 1 to $10 \mathrm{wt} \%$ under industrially-relevant high pressure reaction conditions $\left(120{ }^{\circ} \mathrm{C}, 35\right.$ bar) ${ }^{24}$. Note in Figure 1 that the low dead volume reactor-MS setup employed here allowed us to qualitatively follow the change in catalytic activity from true zero TOS. As observed in Figure 1, the activity is maximal at the start of the reaction and then rapidly declines during the first 20 min on stream followed by a smoother decay until a pseudo-steady state is attained at TOS above $60 \mathrm{~min}$. The qualitative activity trend derived from the continuous monitoring of the MS signal of butenes matches well that observed for the ethylene conversion rates (quantified by offline GC analyses at selected TOS) and is common to all Ni-beta samples irrespective of Ni loading (Figure S1a). It should be pointed out that the ethylene conversion rates displayed by the Ni-beta catalysts at atmospheric pressure are about one order of magnitude lower than those achieved at 35 bar, as one might expect from the positive kinetic effect of the ethylene partial pressure on the oligomerization rate r,13,17,39 $^{\text {Notwithstanding }}$ the differences in activity, the Ni-beta samples exhibit the same dependency of the conversion rate with nickel loading at both 1 and 35 bar, translating into a fairly good linear correlation between the steady state reaction rate at these two pressures (Figure S1b). This observation strongly points toward the same structure for the active nickel species in the working catalysts regardless the reaction pressure, thus validating our experimental approach combining reaction kinetics and in situ FTIR spectroscopy at ambient pressure to disentangle the nature of the active nickel species. Moreover, the absence of an induction period in the activity-TOS curves (Figure 1 and Figure S1a) suggests that the active nickel species are not formed in situ upon contacting the Ni-beta catalysts with ethylene at the studied reaction conditions.

Intriguingly, the online MS analyses of gas phase products revealed the formation of ethane and butane at the very begin- 
ning of the oligomerization reaction (see inset to Figure 1) in the absence of any external source of $\mathrm{H}_{2}$. In fact, a nonnegligible amount of $\mathrm{H}_{2}$ was detected in the gaseous products by GC during the initial reaction stages concurring with the formation of the mentioned saturated hydrocarbons (Figure S2). These aspects will be further discussed later at the view of the results of temperature-resolved FTIR experiments. Furthermore, taking into account the very small crystallite size (20-25 nm) of the Ni-beta catalysts and the absence of oligomers higher than $\mathrm{C}_{8}$ in the product stream of the ambient pressure catalytic experiments, diffusion-related issues and/or extensive pore blockage by retained bulky oligomers can hardly account for the observed initial deactivation. Instead, the initial decline in activity is likely related to changes in the concentration and/or the nature of the available nickel species, as will be shown next based on time-resolved FTIR-CO spectroscopy.

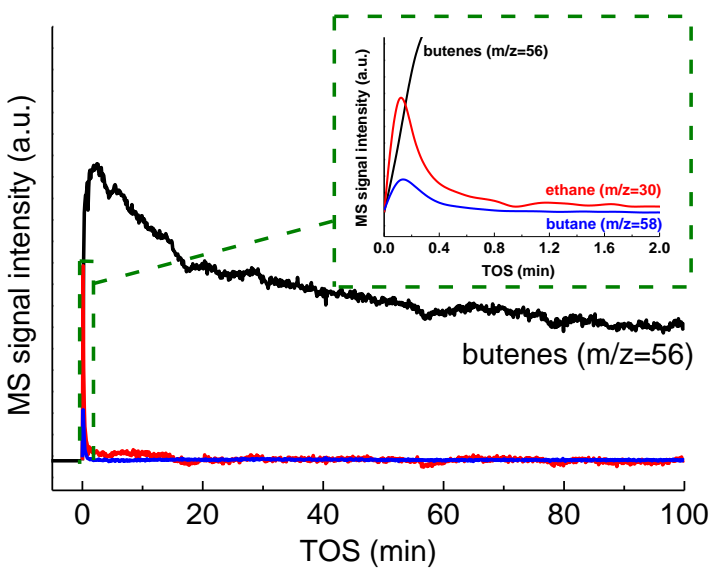

Figure 1. Evolution of the mass spectral $\mathrm{m} / \mathrm{z}$ signals of the main reaction product butenes $(\mathrm{m} / \mathrm{z}=56)$, and the minor products ethane $(\mathrm{m} / \mathrm{z}=30)$ and butane $(\mathrm{m} / \mathrm{z}=58)$ with time-on-stream (TOS) during the reaction of ethylene with $5 \mathrm{Ni}$-beta at $120^{\circ} \mathrm{C}, 1 \mathrm{bar}$, and WHSV of $33 \mathrm{~h}^{-1}$.

The nickel speciation during the in situ reaction of ethylene with 5Ni-beta in the FTIR cell at the same conditions employed in the catalytic experiments $\left(120{ }^{\circ} \mathrm{C}, 1\right.$ bar) was investigated by low temperature $\left(-176^{\circ} \mathrm{C}\right)$ FTIR-CO at selected reaction times, with the first spectrum being recorded just $10 \mathrm{~s}$ after the start of the reaction. The time-resolved FTIR-CO spectra at saturation coverage of Ni-carbonyl bands are shown in Figure 2. The spectrum corresponding to the state of the $5 \mathrm{Ni}$-beta catalyst prior to reaction (zero TOS, spectrum a in Figure 2) shows low-frequency components at 2175, 2166, and $2157 \mathrm{~cm}^{-1}$ ascribed to $\mathrm{CO}$ adducts with, respectively, Brønsted acid sites, aluminols, and silanols, and a signal at $2132 \mathrm{~cm}^{-1}$ attributed to $\mathrm{CO}$ interacting with the catalyst surface via its oxygen atom ${ }^{40-42}$. An IR band at $2143 \mathrm{~cm}^{-1}$ of physically adsorbed $\mathrm{CO}$ is also evident in the spectrum of fresh $5 \mathrm{Ni}$-beta. All the above IR bands were also present in the FTIR-CO spectrum of the bare nanocrystalline $\mathrm{H}$-beta zeolite ${ }^{33}$. Focusing on the nickel-carbonyl region of interest, the most intense IR bands are clearly those peaking at 2214 and $2205 \mathrm{~cm}^{-1}$ of $\mathrm{CO}$ adsorbed on isolated $\mathrm{Ni}^{2+}$ ions counterbalancing the negative charge of the zeolite framework (i.e. at ion exchange positions $)^{33,42-44}$, that is, the nickel species generally considered as the active sites in Ni-aluminosilicate catalysts ${ }^{2,13,15,19,25,26}$. The different $\mathrm{CO}$ vibration frequency for these two ion-exchanged $\mathrm{Ni}^{2+}$ cations signs for a distinct electron accepting capability (i.e. Lewis acid strength) and likely reflects their location at exchange sites in different crystallographic positions within the complex intergrowth structure of zeolite beta ${ }^{45}$. Additionally, a component at $2196 \mathrm{~cm}^{-1}$ attributed to isolated $\mathrm{Ni}^{2+}$ cations grafted on acidic silanols ${ }^{33,44,46}$, such as those associated to internal defects or stacking faults abundantly present in nanocrystalline beta ${ }^{24,47}$, is also seen in the spectrum of the prereacted sample (Figure 2, spectrum a). Likewise, a weak component at $2150 \mathrm{~cm}^{-1}$ of $\mathrm{CO}$ coordinated to unsaturated $\mathrm{Ni}^{2+}$ ions on the surface of bulk-like $\mathrm{NiO}$ particles ${ }^{33,44}$ can be perceived at low $\mathrm{CO}$ coverages (Figure S3), in consistence with the detection by XRD of NiO-related peaks in this sample ${ }^{24}$. Bulk-like $\mathrm{NiO}$ particles, however, are widely regarded as inactive in ethylene oligomerization ${ }^{2,18,25}$. At this point, it should be mentioned that we did not find clear evidences for the presence of $(\mathrm{Ni}-\mathrm{OH})^{+}$species in fresh $5 \mathrm{Ni}$-beta, as indicated by the absence of an IR component at about $3630-3650 \mathrm{~cm}^{-}$ ${ }^{1}$ in the $\mathrm{OH}$ stretching region ${ }^{38,48}$ prior $\mathrm{CO}$ adsorption (Figure S4). Furthermore, IR components at 2138 and $2095 \mathrm{~cm}^{-1}$ characteristic of $\mathrm{Ni}^{+}(\mathrm{CO})_{2}$ adducts ${ }^{24,42}$ were not discerned even at low $\mathrm{CO}$ coverage and, thus, only divalent nickel ions are concluded to exist on the surface of $5 \mathrm{Ni}$-beta in its pre-reacted state, that is, after the thermal treatment in flowing $\mathrm{N}_{2}$ at 300 ${ }^{\circ} \mathrm{C}$ preceding catalysis.

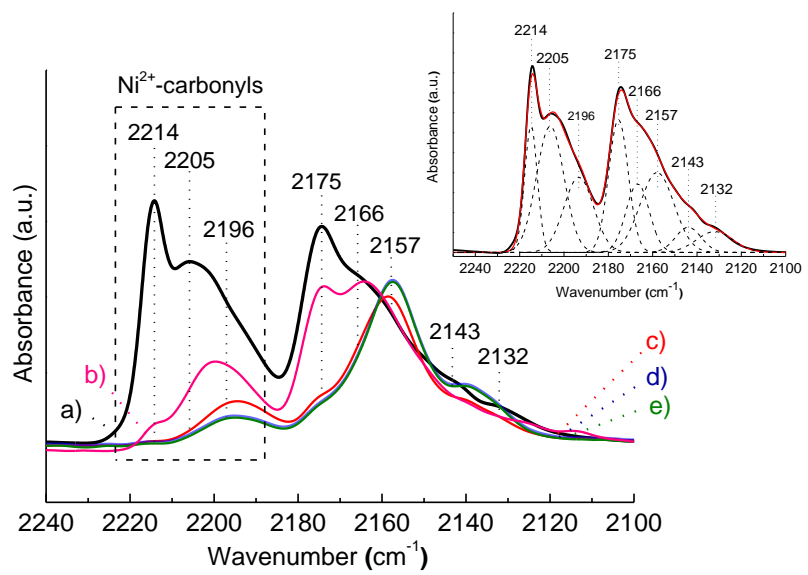

Figure 2. Time-resolved low-temperature FTIR-CO spectra (at $\mathrm{CO}$ saturation of Ni-carbonyl bands) for 5Ni-beta catalyst in its prereacted state (a) and after reaction with ethylene at $120{ }^{\circ} \mathrm{C}$ and 1 bar for $10 \mathrm{~s} \mathrm{(b),} 8 \mathrm{~min}$ (c), $30 \mathrm{~min}$ (d), and $70 \mathrm{~min}$ (e). The deconvoluted spectrum a corresponding to the fresh catalyst is shown at the topright side for better visualization of the individual IR components.

As seen in Figure 2, a remarkable reduction in the intensity of the IR bands of isolated $\mathrm{Ni}^{2+}$ species is noticed already after $10 \mathrm{~s}$ of reaction. The decrease in intensity is particularly drastic for the bands at 2214 and $2205 \mathrm{~cm}^{-1}$ associated to ionexchanged $\mathrm{Ni}^{2+}$ cations, for which their higher frequency relative to the other $\mathrm{Ni}^{2+}$-related bands clearly signs for a stronger Lewis acidity. The intensity of these bands continues decreasing with time and becomes almost negligible after 30 min of reaction. Total extinction of the IR bands of CO interacting with ion-exchanged $\mathrm{Ni}^{2+}$ ions has also been recently reported upon exposing a microcrystalline $\mathrm{Ni}-\mathrm{H}$-beta $(2.2 \mathrm{wt} \%$ $\mathrm{Ni}$ ) catalyst to ethylene flow at $150{ }^{\circ} \mathrm{C}$ for $30 \mathrm{~min}^{25}$. However, 
these authors assigned the ion-exchanged $\mathrm{Ni}^{2+}$ species the role of active sites notwithstanding the significant activity exhibited by the catalyst even after $300 \mathrm{~min}$ of reaction at standard conditions $\left(\mathrm{T}=120{ }^{\circ} \mathrm{C}, \mathrm{P}_{\mathrm{C} 2 \mathrm{H} 4}=25.1 \mathrm{bar}\right)^{25}$. As seen in Figure 2, no further changes in the intensity of the $\mathrm{Ni}^{2+}$-related bands are apparent in the reaction period of 30-70 min, during which isolated $\mathrm{Ni}^{2+}$ ions grafted on silanols (IR band at $2196 \mathrm{~cm}^{-1}$ ) are practically the only nickel species remaining on the surface of 5Ni-beta (excluding those associated to catalyticallyinactive bulk-like $\mathrm{NiO}$ nanoparticles). It is worth noting that the IR band at $2175 \mathrm{~cm}^{-1}$ experiences, as observed for the $\mathrm{Ni}$ related bands, a significant decline in intensity with reaction time (Figure 2), indicating that ethylene also interacts with the surface Brønsted acid sites of 5Ni-beta at the investigated conditions.

The obvious parallelism between the initial decline in activity and the reduction in intensity of the $\mathrm{Ni}^{2+}-\mathrm{CO}$ bands, particularly of those linked to ion-exchanged $\mathrm{Ni}^{2+}$ species, clearly points toward a close relationship between both phenomena. This observation also suggests that the ion-exchanged $\mathrm{Ni}^{2+}$ species, whose associated IR carbonyl bands exhibit the highest frequency and intensity among the Ni-related bands in the pre-reacted 5Ni-beta sample (Figure 2a), are probably those contributing the most to the initial high activity. At this point, it should be noted that monovalent $\mathrm{Ni}^{+}$ions, absent in the fresh sample, readily formed during the catalytic reaction, as corroborated by the observation of their characteristic dicarbonyl bands at 2138 and $2095 \mathrm{~cm}^{-1}$ at low CO coverage (Figure S5). Formation of $\mathrm{Ni}^{+}$species can be accounted for by reduction of $\mathrm{Ni}^{2+}$ with ethylene, as previously reported ${ }^{49,50}$. However, the fact that the intensity of the $\mathrm{Ni}^{+}$-related carbonyl bands and the catalyst activity evolve oppositely with the progress of the reaction strongly points toward their role as spectators rather than as true active sites. On the other hand, detection by FTIR-CO spectroscopy of metallic Ni species, characterized by their monocarbonyl $\left(\mathrm{Ni}^{0}-\mathrm{CO}\right)$ and dicarbonyl $\left(\mathrm{Ni}^{0}-(\mathrm{CO})_{2}\right)$ bands at $2072-2068 \mathrm{~cm}^{-1}$ and $2090 \mathrm{~cm}^{-1}$, respectively, is not straightforward due to overlapping with the band at $2095 \mathrm{~cm}^{-1}$ of $\mathrm{Ni}^{+}-(\mathrm{CO})_{2}$ species ${ }^{42}$. Therefore, we applied $\mathrm{X}$ ray photoelectron spectroscopy (XPS), a highly sensitive surface technique, in order to ascertain whether $\mathrm{Ni}^{0}$ species were present in the $5 \mathrm{Ni}$-beta catalyst. Figure 3 shows the deconvoluted $\mathrm{Ni} 2 \mathrm{p}_{3 / 2} \mathrm{XP}$ spectra for $5 \mathrm{Ni}$-beta after pretreatment in flowing $\mathrm{N}_{2}$ at $300^{\circ} \mathrm{C}$ for $3 \mathrm{~h}$ (a) and after in situ reaction with ethylene at $120^{\circ} \mathrm{C}$ and 1 bar for $2 \mathrm{~h}$ (b). Both spectra exhibited two main components at $857.7 \mathrm{eV}$ and $854.3 \mathrm{eV}$, together with a satellite peak at higher BE, that are assigned to, respectively, highly dispersed $\mathrm{Ni}^{2+}$ ions and $\mathrm{NiO}^{51}$. The small component at $855.5 \mathrm{eV}$ observed in the spectrum of $5 \mathrm{Ni}$-beta after reaction with ethylene for $2 \mathrm{~h}$ (Figure $3 \mathrm{~b}$ ) is related to $\mathrm{Ni}^{+}$species ${ }^{52}$ formed under reaction conditions, as also concluded from FTIR-CO (Figure S5). Moreover, the absence of a component located at ca. $852 \mathrm{eV}^{52}$ indicates that $\mathrm{Ni}^{0}$ species were not present on the surface of $5 \mathrm{Ni}$-beta both before and after reaction.



Figure 3. Ni2 $\mathrm{p}_{3 / 2} \mathrm{XP}$ spectra of $5 \mathrm{Ni}$-beta catalyst in its fresh state (a) and after in situ reaction with ethylene at $120^{\circ} \mathrm{C}$ and 1 bar for $2 \mathrm{~h}$ (b).

Parallel to the decline with time-on-stream of the catalytic activity and the intensity of the $\mathrm{Ni}^{2+}$ - and $\mathrm{H}^{+}$-related carbonyl bands we also observed the development of IR bands, resistant to evacuation, characteristic of $\mathrm{CH}_{3}$ and $\mathrm{CH}_{2}$ groups ${ }^{34,53-55}$ that evidence the formation of acyclic hydrocarbon species (Figure S6) irreversibly adsorbed (hence, playing the role of spectators) on both the nickel cations and the Brønsted acid sites of $5 \mathrm{Ni}$-beta. The fact that for the series of Ni-beta catalysts the intensity of these bands raises with the increase in nickel content (Figure S7), and therefore with the decrease in the amount of available Brønsted acid sites ${ }^{24}$, suggests that the hydrocarbon spectator species are mainly located at the $\mathrm{Ni}^{2+}$ sites, most likely at those in ion exchange positions for which the corresponding IR-CO bands resulted the most affected during catalysis.

Collectively, our results advocate for isolated $\mathrm{Ni}^{2+}$ ions grafted on silanols as the relevant surface active nickel sites in the working Ni-beta catalysts rather than the generally accepted nickel cations counterbalancing the negative charge of the zeolite framework. This arises from the milder Lewis acid character of the former species, which provides a more favorable binding of the reactant ethylene allowing easy desorption of products in opposition to the more acidic ion-exchanged $\mathrm{Ni}^{2+}$ cations on which the intermediates become irreversibly adsorbed causing their blockage short after the beginning of the oligomerization reaction.

Initiation mechanism of ethylene oligomerization on $\mathrm{Ni}$ beta. In the next step of our study, the mechanism of activation-oligomerization of ethylene on $5 \mathrm{Ni}$-beta was investigated by temperature-resolved FTIR spectroscopy under dynamic flow of ethylene at constant pressure of $1.5 \mathrm{mbar}$ to ensure detection of the adsorbed $\mathrm{Ni} \cdots \mathrm{C}_{\mathrm{x}} \mathrm{H}_{\mathrm{y}}$ molecular complexes. A low initial adsorption temperature of $-100{ }^{\circ} \mathrm{C}$ was adopted here to prevent reaction of ethylene, which has been reported to occur fast on Ni-aluminosilicates even at room temperature $^{2,3,23,37}$. Subsequently, the temperature in the IR cell was progressively increased up to $120{ }^{\circ} \mathrm{C}$ enabling the oligomerization reaction to proceed at a sufficiently slow rate to have 
chance for capturing the involved intermediates while simultaneously analyzing the desorbed products by online MS.

The temperature-resolved FTIR-ethylene spectra in different IR regions are presented in Figure 4 at selected temperatures in the range of $-100{ }^{\circ} \mathrm{C}$ to $120{ }^{\circ} \mathrm{C}$. At the initial adsorption temperature of $-100{ }^{\circ} \mathrm{C}$, ethylene interacted weakly with the surface sites of the pristine H-beta zeolite, as indicated by the IR bands at 3093, 3065, 3005, 2975, 1613, 1440, and 1340 $\mathrm{cm}^{-1}$ (Figure S8) of physically adsorbed ethylene ${ }^{34,53}$. Differently, at $-100{ }^{\circ} \mathrm{C}$ ethylene adsorbed stronger on $5 \mathrm{Ni}$-beta producing additional IR bands at 1587 and $1424 \mathrm{~cm}^{-1}$ (spectrum 1 in Figure 4 and Figure $\mathrm{S} 9$ for a clearer visualization) attributable to the $v(\mathrm{C}=\mathrm{C})$ stretching and $\delta\left(\mathrm{CH}_{2}\right)$ bending vibrations, respectively, of ethylene $\pi$-bonded to the cationic $\mathrm{Ni}^{2+}$ sites $^{53,56}$. Moreover, the presence of $\mathrm{C}-\mathrm{H}$ vibration bands at 3277,3227 , and $3189 \mathrm{~cm}^{-1}$ (superimposed to broad bands of perturbed $\mathrm{O}-\mathrm{H}$ groups), and a weak $\mathrm{C} \equiv \mathrm{C}$ vibration feature at $2164 \mathrm{~cm}^{-1}$ (Figure S9) unambiguously support the formation of acetylenic $(\mathrm{HC} \equiv \mathrm{C}-)$ species ${ }^{57}$ at $-100{ }^{\circ} \mathrm{C}$, remaining visible up to a temperature of $-25{ }^{\circ} \mathrm{C}$ (Figure $4 \mathrm{a}$ ). These features indicate that ethylene readily undergoes $\mathrm{C}-\mathrm{H}$ bond dissociation following its coordination to the $\mathrm{Ni}^{2+}$ sites, leading to the formation of the observed acetylenic species. Hence, during the dissociative adsorption of ethylene the release of $\mathrm{H}$ species to the catalyst surface must have occurred to generate these acetylenic species. Taking into account that both $\mathrm{H}_{2}$ and alkanes have been detected by GC-MS at very short reaction times in the absence of any external source of hydrogen, our results suggest that the $\mathrm{H}$ species (i.e. $\mathrm{H}^{+} / \mathrm{H}^{-}$ions and/or $\mathrm{H}$. radicals) may recombine and desorb as molecular $\mathrm{H}_{2}$ (Figure S2) and also react with weakly adsorbed $\pi$-bonded ethylene or intermediate species (e.g. Ni-alkyl) located at a suitable distance to form $\mathrm{C}_{2}$ and $\mathrm{C}_{4}$ alkanes as self-hydrogenated products. Based on the above observations, it seems reasonable that the formation of $\mathrm{H}_{2}$, ethane, and butane decreases once the ethylene-to-acetylene conversion is over and the generated $\mathrm{H}$ species have been consumed. The formation of alkanes is further supported by the presence of IR components at 2942 and $2880 \mathrm{~cm}^{-1}$ related to ethane ${ }^{58}$ in the temperature range from $-58{ }^{\circ} \mathrm{C}$ to $-25{ }^{\circ} \mathrm{C}$ (Figure 4b) and its release to the gas phase at ca. $-25^{\circ} \mathrm{C}$, as evidenced in the online MS analyses (Figure 5). a)

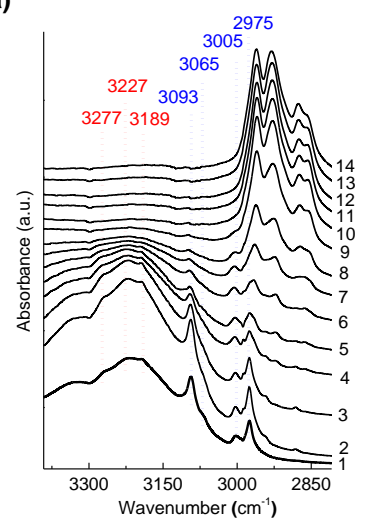

c)

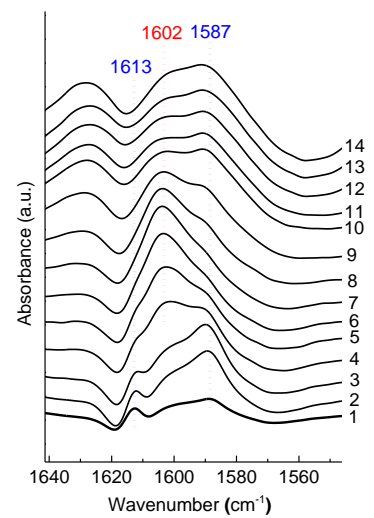

d)

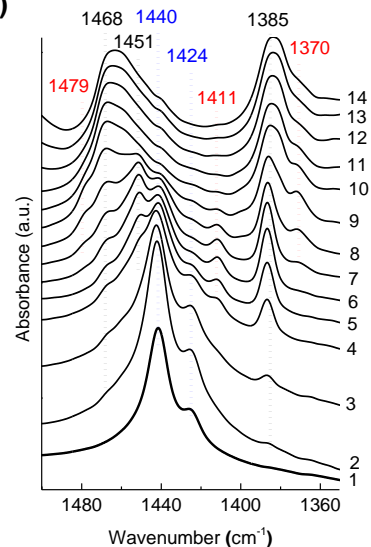

Figure 4. Temperature-resolved FTIR spectra in different regions (ad) during the in situ reaction of ethylene with $5 \mathrm{Ni}$-beta at a constant pressure of 1.5 mbar: (1) $-100{ }^{\circ} \mathrm{C},(2)-58{ }^{\circ} \mathrm{C}$, (3) $-48{ }^{\circ} \mathrm{C}$, (4) $-33{ }^{\circ} \mathrm{C}$, (5) $-25{ }^{\circ} \mathrm{C}$, (6) $-15{ }^{\circ} \mathrm{C}$, (7) $-4{ }^{\circ} \mathrm{C}$, (8) $5{ }^{\circ} \mathrm{C}$, (9) $26{ }^{\circ} \mathrm{C}$, (10) $55^{\circ} \mathrm{C}$, (11) $66^{\circ} \mathrm{C}$, (12) $88^{\circ} \mathrm{C}$, (13) $107{ }^{\circ} \mathrm{C}$, (14) $120^{\circ} \mathrm{C}$. Spectra have been upshifted for the sake of clarity.

Concomitant to the onset of detection of acetylenic species at $-100{ }^{\circ} \mathrm{C}$, a weak feature at $1814 \mathrm{~cm}^{-1}$ assignable to the stretching vibration of $\mathrm{Ni}-\mathrm{H}$ species ${ }^{59,60}$ was also perceived (Figure S10a). The absence of this band upon adsorbing deuterated ethylene (Figure S10b) adds support to this assignment. It seems plausible that the $\mathrm{H}$ species released to the catalyst surface during the formation of acetylenic species may also react with a nearby $\mathrm{Ni}^{2+}$ Lewis acid site leading to the observed Ni-H species. Thus, we cannot rule out this as a possible route for the creation of active $\mathrm{Ni}-\mathrm{H}$ Cossee-Arlman sites. However, it is worth mentioning that we do not observe any correlation between the formation of such $\mathrm{Ni}-\mathrm{H}$ species and the detection of butenes in the gas phase products, as it will be discussed later. Therefore, we consider only a minor contribution, if any, of these $\mathrm{Ni}-\mathrm{H}$ species to the overall dimerization path. The fact that the $\mathrm{Ni}-\mathrm{H}$ species are detected only after contacting ethylene with the 5Ni-beta catalyst allows us to exclude, in contrast to what has been proposed in recent studies ${ }^{13,26}$ their formation by reaction of the originally present nickel cations with Brønsted acid sites during the thermal pretreatment of the catalyst. In turn, new IR bands at 3015, 1411 , and $1602 \mathrm{~cm}^{-1}$ corresponding to, respectively, the $\mathrm{C}-\mathrm{H}$ stretching, $\mathrm{C}-\mathrm{H}$ bending, and $\mathrm{C}=\mathrm{C}$ vibrations of vinyl-type $\left(\mathrm{CH}_{2}=\mathrm{CH}-\right)$ species ${ }^{61,62}$ emerge at a temperature of around -33 ${ }^{\circ} \mathrm{C}$ (Figure 4) accompanied by an increase in intensity of the $\mathrm{Ni}-\mathrm{H}$ band (Figure S10a). The vinyl bands reach their maximum at about $-4{ }^{\circ} \mathrm{C}$ and then gradually decline at increasing temperatures until their intensity practically vanish at $55^{\circ} \mathrm{C}$. Meanwhile, bands at 1479 and $1370 \mathrm{~cm}^{-1}$ related to the $\mathrm{C}-\mathrm{H}$ bending vibrations of, respectively, $\mathrm{CH}_{2}$ and $\mathrm{CH}_{3}$ species of ethyl groups ${ }^{56}$ emerge at $-4{ }^{\circ} \mathrm{C}$ and remain visible up to the temperature of $55^{\circ} \mathrm{C}$ (Figure $4 \mathrm{~d}$ ) above which the IR bands of $\mathrm{Ni}-\mathrm{H}$ and vinyl species are almost extinguished.

Concurrently to the onset of detection of the vinyl-type intermediates at around $-33{ }^{\circ} \mathrm{C}$, butenes start to be observed in the online MS analysis of desorbing gas phase products (Figure 5). The fact that their concentration first increases smoothly up to $55{ }^{\circ} \mathrm{C}$ and then raises exponentially beyond this temperature, coinciding with the sharp decline in intensity of the vinyl-related bands (Figure 4), signs for a relevant role of nickel-vinyl-hydride species in the initial activation and di- 
merization of ethylene on the active nickel sites. Consecutive to the detection of butenes, butane is observed by MS at $20^{\circ} \mathrm{C}$ (Figure 5) evidencing the occurrence of butenes selfhydrogenation through their reaction with the $\mathrm{H}$ species generated upon the dissociative adsorption of ethylene, as discussed beforehand. The intensity of the butane MS signal grows parallel to that of butenes at increasing temperatures, attains its maximum about $10 \mathrm{~min}$ after reaching $120{ }^{\circ} \mathrm{C}$ and then decreases due, probably, to the consumption of the surface $\mathrm{H}$ species. These observations concur with the formation of ethane and butane during the first events of the oligomerization reaction in the experiment performed at $120{ }^{\circ} \mathrm{C}$ and $1 \mathrm{bar}$ (Figure 1).

Furthermore, IR bands corresponding to the stretching and bending vibration modes of $\mathrm{CH}_{3}\left(v_{\mathrm{as}}=2960 \mathrm{~cm}^{-1} ; v_{\mathrm{s}}=2873 \mathrm{~cm}^{-}\right.$ $\left.{ }^{1} ; \delta=1385 \mathrm{~cm}^{-1}\right)$ and $\mathrm{CH}_{2}\left(v_{\mathrm{as}}=2926 \mathrm{~cm}^{-1} ; v_{\mathrm{s}}=2855 \mathrm{~cm}^{-1} ; \delta=\right.$ 1468 and $\left.1451 \mathrm{~cm}^{-1}\right)$ groups are detected at temperatures as low as $-48^{\circ} \mathrm{C}$ (Figure 4). The fact that their intensities grow at increasing temperatures without evolving into other species until the completion of the experiment, even after subsequent evacuation of the IR cell, prompts us to assign the associated hydrocarbon species the role of spectators. Due to their almost identical bond vibration frequencies, these spectator species could be considered the precursors of the irreversibly adsorbed aliphatic acyclic hydrocarbons (Figure S6) that caused the blockage of the most acidic ion-exchanged $\mathrm{Ni}^{2+}$ ions, as discussed in the first part of this study. The detection in the temperature-resolved FTIR-ethylene experiments of the hydrocarbon spectators at temperatures below that at which the vinylrelated IR bands start to develop suggests that the later intermediates are mostly formed on the mildly acidic grafted $\mathrm{Ni}^{2+}$ cations which we propose here as the most likely active nickel sites in working Ni-beta catalysts.

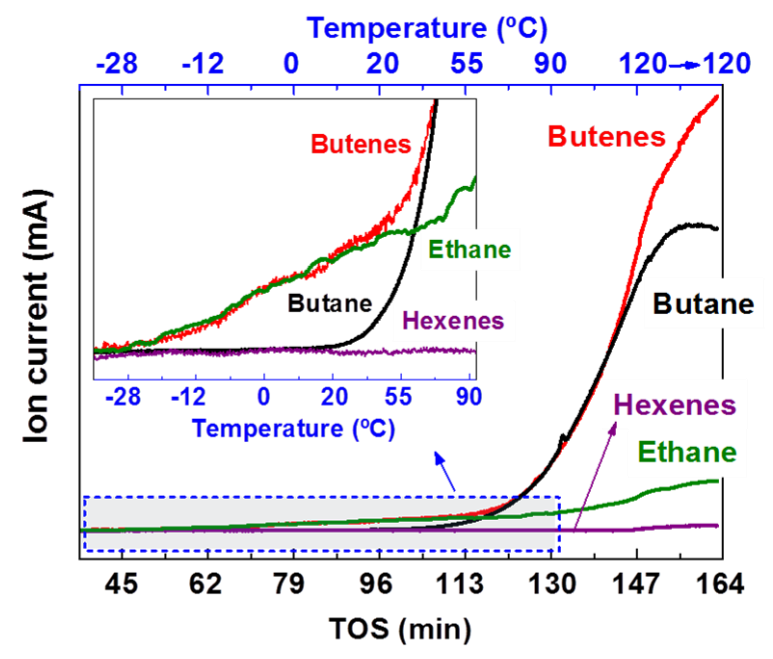

Figure 5. Continuous monitoring by online MS of the gas phase products leaving the IR cell during the exposure of $5 \mathrm{Ni}$-beta to 1.5 mbar of flowing ethylene at increasing temperatures from $-100{ }^{\circ} \mathrm{C}$ to $120^{\circ} \mathrm{C}$.

It should be mentioned that the fact that butadiene was not detected by MS in the desorbing products during the whole FTIR-ethylene experiment and the lack of any spectroscopic evidence for the formation of new $\mathrm{OH}$ groups, whose IR bands would be expected at 3610 and $3640 \mathrm{~cm}^{-1}$ (see Figure S11), prompts us to rule out the formation of the $\mathrm{Ni}-\mathrm{H}$ (or $\mathrm{Ni}$ ethene-H) Cossee-Arlman centers initiated by proton transfer as recently suggested based on $\mathrm{DFT}^{26}$ (Scheme S1). Moreover, the detection in the present study of vinyl and terminal $\mathrm{CH}_{3}$ groups in the reaction intermediates seems also discrepant with an oligomerization pathway involving metallacycles ${ }^{15}$ (Scheme S2). Conversely, based on our experimental results evidencing a clear correspondence between the temperatureevolution for the detected intermediates and the desorbing products, we propose the mechanism depicted in Scheme 2 for the initial activation and dimerization of ethylene on Ni-beta. According to this, ethylene first coordinates via $\pi$-bonding to the $\mathrm{Ni}^{2+}$ site and then activates its $\mathrm{C}-\mathrm{H}$ bond through oxidative addition leading to a nickel-ethenyl-hydride intermediate. Subsequently, dimerization proceeds similar to the classical Cossee-Arlman pathway by insertion of a second ethylene molecule into the $\mathrm{Ni}-\mathrm{H}$ bond generating a nickel-ethenyl-ethyl species. Chain termination likely occurs by reductive elimination (i.e. the step reverse to the initial oxidative activation) releasing 1-butene and restoring the original $\mathrm{Ni}^{2+}$ center, thus closing the catalytic cycle.

Scheme 2. Simplified catalytic cycle proposed for the activation and dimerization of ethylene on the active $\mathrm{Ni}^{2+}$ centers of Ni-beta catalysts.

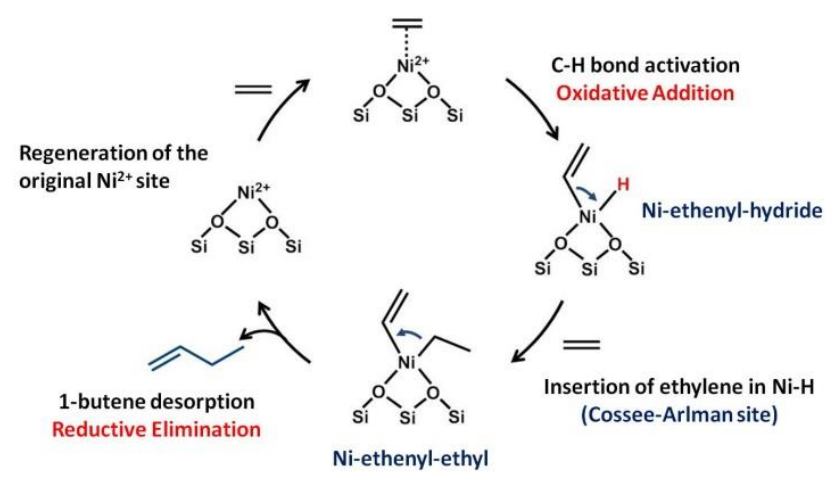

\section{CONCLUSIONS}

In summary, the applied experimental methodology coupling reaction kinetics with in situ FTIR spectroscopy at $120^{\circ} \mathrm{C}$ and 1 bar with unparalleled high initial temporal resolution enabled us to identify isolated $\mathrm{Ni}^{2+}$ ions grafted on acidic silanols, characterized by an IR band at $2196 \mathrm{~cm}^{-1}$, as the main active nickel species in the oligomerization of ethylene on working Ni-beta catalysts. Moreover, a mechanism for the initial activation-dimerization of ethylene on the active $\mathrm{Ni}^{2+}$ centers is proposed based, for the first time, on the intermediates experimentally detected by temperature-resolved FTIRethylene spectroscopy coupled to online MS analysis of desorbed products. This mechanism entails the oxidative $\mathrm{C}-\mathrm{H}$ bond activation of ethylene on the $\mathrm{Ni}^{2+}$ site leading to a nickelethenyl-hydride intermediate that subsequently evolves similar to the classical Cossee-Arlman mechanism. Our approach paves the way to decipher the structure of active $\mathrm{Ni}$ sites and the likely mechanism operating during the functioning of other promising Ni-based catalysts (e.g. Ni-Al-MCM-41, Ni-SiO ${ }_{2}$ $\mathrm{Al}_{2} \mathrm{O}_{3}$, etc.) as an essential step towards the implementation of a greener ethylene oligomerization technology. 


\section{ASSOCIATED CONTENT}

Supporting Information. Experimental details, reaction mechanisms, and data (PDF). This material is available free of charge via the Internet at http://pubs.acs.org.

\section{AUTHOR INFORMATION}

\section{Corresponding Author}

*amart@itq.upv.es

\section{ORCID}

Agustín Martínez: 0000-0002-9974-1567

\section{Author Contributions}

All authors contributed equally.

\section{Notes}

The authors declare no competing financial interest.

\section{ACKNOWLEDGMENTS}

This work was supported by the MINECO of Spain through the Severo Ochoa Program for Centers of Excellence (SEV 20160683) and ENE2014-5761-R project. The authors extend their acknowledgement to the EU project OCMOL ("Oxidative Coupling of Methane followed by Oligomerization to Liquids", $7^{\text {th }}$ Framework Programme, GA no 228953).

\section{REFERENCES}

(1) Skupinska, J. Oligomerization of $\alpha$-olefins to higher oligomers. Chem. Rev. 1991, 91, 613-648.

(2) Finiels, A.; Fajula, F.; Hulea, V. Nickel-based solid catalysts for ethylene oligomerization - a review. Catal. Sci. Technol. 2014, 4, 2412-2426.

(3) Keim, W. Oligomerization of Ethylene to $\alpha$-Olefins: Discovery and Development of the Shell Higher Olefin Process (SHOP). Angew. Chem., Int. Ed. 2013, 52, 12492-12496.

(4) McGuinness, D. S. Olefin Oligomerization via Metallacycles: Dimerization, Trimerization, Tetramerization, and Beyond. Chem. Rev. 2011, 111, 2321-2341.

(5) Al-Jarallah, A. M.; Anabtawi, J. A.; Siddiqui, M. A. B.; Aitani, A. M.; Al-Sa'doun, A. W. Ethylene dimerization and oligomerization to butene- 1 and linear $\alpha$-olefins: a review of catalytic systems and processes. Catal. Today 1992, 14, 1-121.

(6) Bruijnincx, P. C. A.; Weckhuysen, B. M. Shale Gas Revolution: An Opportunity for the Production of Biobased Chemicals?. Angew. Chem., Int. Ed. 2013, 52, 11980-11987.

(7) Galadima, A.; Muraza, O. Revisiting the oxidative coupling of methane to ethylene in the golden period of shale gas: A review. $J$. Ind. Eng. Chem. 2016, 37, 1-13.

(8) Cossee, P. Ziegler-Natta catalysis. I. Mechanism of polymerization of $\alpha$-olefins with Ziegler-Natta catalysts. J. Catal. 1964, 3, 80-88. (9) Arlman, E. J.; Cossee, P. Ziegler-Natta catalysis. III. Stereospecific polymerization of propene with the catalyst system $\mathrm{TiCl}_{3}-\mathrm{AlEt}_{3} . J$. Catal. 1964, 3, 99-104.

(10) Heveling, J.; Nicolaides, C. P.; Scurrell, M. S. Identification of novel catalysts and conditions for the highly efficient and stable heterogeneous oligomerization of ethylene. J. Chem. Soc., Chem. Commun. 1991, 126-127.

(11) Heveling, J.; Nicolaides, C. P.; Scurrell, M. S. Catalysts and conditions for the highly efficient, selective and stable heterogeneous oligomerisation of ethylene. Appl. Catal. A 1998, 173, 1-9.

(12) Heydenrych, M. D.; Nicolaides, C. P.; Scurrell, M. S. Oligomerization of Ethene In a Slurry Reactor Using a Nickel(II)-Exchanged Silica-Alumina Catalyst. J. Catal. 2001, 197, 49-57.
(13) Toch, K.; Thybaut, J. W.; Marin, G. B. Ethene oligomerization on $\mathrm{Ni}-\mathrm{SiO}_{2}-\mathrm{Al}_{2} \mathrm{O}_{3}$ : Experimental investigation and Single-Event MicroKinetic modeling. Appl. Catal. A 2015, 489, 292-304.

(14) Wendt, G.; Finster, J.; Schoellner, R.; Siegel, H. Structural and catalytic properties of nickel(II) oxide-aluminum oxide/silicon dioxide catalysts for the dimerization and isomerization of olefins. Stud. Surf. Sci. Catal. 1981, 7, 978-992.

(15) Andrei, R. D.; Popa, M. I.; Fajula, F.; Hulea, V. Heterogeneous oligomerization of ethylene over highly active and stable Ni-AlSBA15 mesoporous catalysts. J. Catal. 2015, 323, 76-84.

(16) Hartmann, M.; Poeppl, A.; Kevan, L. Ethylene Dimerization and Butene Isomerization in Nickel-Containing MCM-41 and Al-MCM41 Mesoporous Molecular Sieves: An Electron Spin Resonance and Gas Chromatography Study. J. Phys. Chem. 1996, 100, 9906-9910.

(17) Hulea, V.; Fajula, F. Ni-exchanged AlMCM-41 - An efficient bifunctional catalyst for ethylene oligomerization. J. Catal. 2004, 225, 213-222.

(18) Lacarriere, A.; Robin, J.; Swierczynski, D.; Finiels, A.; Fajula, F.; Luck, F.; Hulea, V. Distillate-Range Products from Non-Oil-Based Sources by Catalytic Cascade Reactions. ChemSusChem 2012, 5, 1787-1792.

(19) Lallemand, M.; Finiels, A.; Fajula, F.; Hulea, V. Nature of the Active Sites in Ethylene Oligomerization Catalyzed by Ni-Containing Molecular Sieves: Chemical and IR Spectral Investigation. J. Phys. Chem. C 2009, 113, 20360-20364.

(20) Lallemand, M.; Finiels, A.; Fajula, F.; Hulea, V. Continuous stirred tank reactor for ethylene oligomerization catalyzed by NiMCM-41. Chem. Eng. J. 2011, 172, 1078-1082.

(21) Bonneviot, L.; Olivier, D.; Che, M. Dimerization of olefins with nickel-surface complexes in X-type zeolite or on silica. J. Mol. Catal. 1983, 21, 415-430.

(22) Lallemand, M.; Finiels, A.; Fajula, F.; Hulea, V. Catalytic oligomerization of ethylene over Ni-containing dealuminated $\mathrm{Y}$ zeolites. Appl. Catal. A 2006, 301, 196-201.

(23) Lallemand, M.; Rusu, O. A.; Dumitriu, E.; Finiels, A.; Fajula, F.; Hulea, V. NiMCM-36 and NiMCM-22 catalysts for the oligomerization: Effect of zeolite texture and nickel cations/acid sites ratio. Appl. Catal. A 2008, 338, 37-43.

(24) Martinez, A.; Arribas, M. A.; Concepcion, P.; Moussa, S. New bifunctional Ni-H-Beta catalysts for the heterogeneous oligomerization of ethylene. Appl. Catal. A 2013, 467, 509-518.

(25) Henry, R.; Komurcu, M.; Ganjkhanlou, Y.; Brogaard, R. Y.; Lu, L.; Jens, K.-J.; Berlier, G.; Olsbye, U. Ethene oligomerization on nickel microporous and mesoporous-supported catalysts: Investigation of the active sites. Catal. Today 2018, 299, 154-163.

(26) Brogaard, R. Y.; Olsbye, U. Ethene Oligomerization in NiContaining Zeolites: Theoretical Discrimination of Reaction Mechanisms. ACS Catal. 2016, 6, 1205-1214.

(27) Elev, I. V.; Shelimov, B. N.; Kazanskii, V. B. The Role of $\mathrm{Ni}^{+}$ Ions in the activity of NiCaY Zeolite catalysts for Ethylene Dimerization. J. Catal. 1984, 89, 470-477.

(28) Hartmann, M.; Poppl, A.; Kevan, L. Formation and Stability of Ni(I) Ions in MCM-41 Mesoporous Molecular Sieves. J. Phys. Chem. 1995, 99, 17494-17496.

(29) Ng, F. T. T.; Creaser, D. C. Ethylene dimerization over modified nickel exchanged Y-zeolite. Appl. Catal. A 1994, 119, 327-339.

(30) Sohn, J. R.; Park, W. C. The roles of active sites of nickel sulphate supported on $\gamma-\mathrm{Al}_{2} \mathrm{O}_{3}$ for ethylene dimerization. Appl. Catal. A 2003, 239, 269-278.

(31) Sohn, J. R.; Park, W. C.; Kim, H. W. Characterization of Nickel Sulfate Supported on $\gamma-\mathrm{Al}_{2} \mathrm{O}_{3}$ for Ethylene Dimerization and Its Relationship to Acidic Properties. J. Catal. 2002, 209, 69-74.

(32) Sohn, J. R.; Park, W. C.; Park, S.-E. Characterization of Nickel Sulfate Supported on $\mathrm{SiO}_{2}-\mathrm{Al}_{2} \mathrm{O}_{3}$ for Ethylene Dimerization and Its Relationship to Acidic Properties. Catal. Lett. 2002, 81, 259-264.

(33) Moussa, S.; Arribas, M. A.; Concepcion, P.; Martinez, A. Heterogeneous oligomerization of ethylene to liquids on bifunctional $\mathrm{Ni}$ based catalysts: The influence of support properties on nickel speciation and catalytic performance. Catal. Today 2016, 277, 78-88.

(34) Tanaka, M.; Itadani, A.; Kuroda, Y.; Iwamoto, M. Effect of Pore Size and Nickel Content of Ni-MCM-41 on Catalytic Activity for 
Ethene Dimerization and Local Structures of Nickel Ions. J. Phys. Chem. C 2012, 116, 5664-5672.

(35) Agirrezabal-Telleria, I.; Iglesia, E. Stabilization of active, selective, and regenerable $\mathrm{Ni}$-based dimerization catalysts by condensation of ethene within ordered mesopores. J. Catal. 2017, 352, 505-514.

(36) Forget, S.; Olivier-Bourbigou, H.; Delcroix, D. Homogeneous and Heterogeneous Nickel-Catalyzed Olefin Oligomerization: Experimental Investigation for a Common Mechanistic Proposition and Catalyst Optimization. ChemCatChem 2017, 9, 2408-2417.

(37) Metzger, E. D.; Comito, R. J.; Hendon, C. H.; Dinca, M. Mechanism of Single-Site Molecule-Like Catalytic Ethylene Dimerization in Ni-MFU-41. J. Am. Chem. Soc. 2017, 139, 757-762.

(38) Borfecchia, E.; Lomachenko, K. A.; Giordanino, F.; Falsig, H.; Beato, P.; Soldatov, A. V.; Bordiga, S.; Lamberti, C. Revisiting the nature of $\mathrm{Cu}$ sites in the activated $\mathrm{Cu}-\mathrm{SSZ}-13$ catalyst for SCR reaction. Chem. Sci. 2015, 6, 548-563.

(39) Nicolaides, C. P.; Scurrell, M. S.; Semano, P. M. Nickel silicaalumina catalysts for ethene oligomerization - control of the selectivity to 1-alkene products. Appl. Catal. A 2003, 245, 43-53.

(40) Góra-Marek, K.; Datka, J. IR studies of OH groups in mesoporous aluminosilicates. Appl. Catal. A 2006, 302, 104-109.

(41) Hensen, E. J. M.; Poduval, D. G.; Degirmenci, V.; Ligthart, D. A. J. M.; Chen, W.; Mauge, F.; Rigutto, M. S.; Veen, J. A. R. V. Acidity Characterization of Amorphous Silica-Alumina. J. Phys. Chem. C 2012, 116, 21416-21429.

(42) Penkova, A.; Dzwigaj, S.; Kefirov, R.; Hadjiivanov, K.; Che, M. Effect of the Preparation Method on the State of Nickel Ions in BEA Zeolites. A Study by Fourier Transform Infrared Spectroscopy of Adsorbed CO and NO, Temperature-Programmed Reduction, and XRay Diffraction. J. Phys. Chem. C 2007, 111, 8623-8631.

(43) Góra-Marek, K.; Glanowska, A.; Datka, J. Quantitative IR studies of the concentration of different nickel sites in NiZSM-5 zeolites. Microporous Mesoporous Mater. 2012, 158, 162-169.

(44) Mihaylov, M.; Hadjiivanov, K. FTIR Study of CO and NO adsorption and coadsorption on Ni-ZSM-5 and $\mathrm{Ni} / \mathrm{SiO}_{2}$. Langmuir 2002, 18, 4376-4383.

(45) Dedecek, J.; Capek, L.; Kaucky, D.; Sobalik, Z.; Wichterlova, B. Siting and Distribution of the Co Ions in Beta Zeolite: A UV-Vis-NIR and FTIR Study. J. Catal. 2002, 211, 198-207.

(46) Hadjiivanov, K.; Mihaylov, M.; Klissurski, D.; Stefanov, P.; Abadjieva, N.; Vassileva, E.; Mintchev, L. Characterization of $\mathrm{Ni} / \mathrm{SiO}_{2}$ Catalysts Prepared by Successive Deposition and Reduction of $\mathrm{Ni}^{2+}$ Ions. J. Catal. 1999, 185, 314-323.

(47) Gabrienko, A. A.; Danilova, I. G.; Arzumanov, S. S.; Toktarev, A. V.; Freude, D.; Stepanov, A. G. Strong acidity of silanol groups of zeolite beta: Evidence from the studies by IR spectroscopy of adsorbed CO and ${ }^{1} \mathrm{H}$ MAS NMR. Microporous Mesoporous Mater. 2010, 131, 210-216.

(48) Hall, D. S.; Lockwood, D. J.; Poirier, S.; Bock, C.; MacDougall, B. R. Raman and Infrared Spectroscopy of $\alpha$ and $\beta$ Phases of Thin Nickel Hydroxide Films Electrochemically Formed on Nickel. $J$. Phys. Chem. A 2012, 116, 6771-6784.
(49) Cai, T. Studies of a new alkene oligomerization catalyst derived from nickel sulfate. Catal. Today 1999, 51, 153-160.

(50) Cai, T.; Cao, D.; Song, Z.; Li, L. Catalytic behavior of $\mathrm{NiSO}_{4} / \gamma-$ $\mathrm{Al}_{2} \mathrm{O}_{3}$ for ethene dimerization. Appl. Catal. A 1993, 95, L1-L7.

(51) Baran, R.; Kaminska, I. I.; Srebowata, A.; Dzwigaj, S. Selective hydrodechlorination of 1,2-dichloroethane on NiSiBEA zeolite catalyst: Influence of the preparation procedure on a high dispersion of $\mathrm{Ni}$ centers. Microporous Mesoporous Mater. 2013, 169, 120-127.

(52) Dominick, R.; Held, G.; Witte, P.; Steinrück, H.-P. The transition from oxygen chemisorption to oxidation of ultra-thin Ni layers on Cu(111). J. Chem. Phys. 2001, 115, 1902-1908.

(53) Groppo, E.; Lamberti, C.; Bordiga, S.; Spoto, G.; Damin, A.; Zecchina, A. FTIR Investigation of the $\mathrm{H}_{2}, \mathrm{~N}_{2}$, and $\mathrm{C}_{2} \mathrm{H}_{4}$ Molecular Complexes Formed on the $\mathrm{Cr}$ (II) Sites in the Phillips Catalyst: a Preliminary Step in the understanding of a Complex System. J. Phys. Chem. B 2005, 109, 15024-15031.

(54) Groppo, E.; Lamberti, C.; Bordiga, S.; Spoto, G.; Zecchina, A. The Structure of Active Centers and the Ethylene Polymerization Mechanism on the $\mathrm{Cr} / \mathrm{SiO}_{2}$ Catalyst: A Frontier for the Characterization Methods. Chem. Rev. 2005, 105, 115-183.

(55) Groppo, E.; Lamberti, C.; Bordiga, S.; Spoto, G.; Zecchina, A. In situ FTIR spectroscopy of key intermediates in the first stages of ethylene polymerization on the $\mathrm{Cr} / \mathrm{SiO} 2$ Phillips catalyst: Solving the puzzle of the initiation mechanism?. J. Catal. 2006, 240, 172-181.

(56) Scarano, D.; Spoto, G.; Bordiga, S.; Carnelli, L.; Ricchiardi, G.; Zecchina, A. Spectroscopic Studies (UV-vis and FTIR) of CO and Ethene Molecular Complexes and of Ethene Oligomerization on $\alpha$ $\mathrm{Cr}_{2} \mathrm{O}_{3}$ Surfaces. Langmuir 1994, 10, 3094-3104.

(57) Castellanos, I.; Marie, O. An operand FT-IR study of the $\mathrm{NO}_{\mathrm{x}}$ SCR over Co-HFER and Fe-HFER using acetylene as a reducing agent. Catal. Today 2017, 283, 54-65.

(58) Kazansky, V. B.; Pidko, E. A. Intensities of IR Stretching Bands as a Criterion of Polarization and Initial Chemical Activation of Adsorbed Molecules in Acid Catalysis. Ethane Adsorption and Dehydrogenation by Zinc Ions in ZnZSM-5 Zeolite. J. Phys. Chem. B 2005, 109, 2103-2108.

(59) Ramakrishnan, S.; Chakraborty, S.; Brennessel, W. W.; Chidsey, C. E. D.; Jones, W. D. Rapid oxidative hydrogen evolution from a family of square-planar nickel hydride complexes. Chem. Sci. 2016, 7, 117-127.

(60) Eberhardt, N. A.; Guan, H. Nickel Hydride Complexes. Chem. Rev. 2016, 116, 8373-8426.

(61) Nikow, M.; Wilhelm, M. J.; Dai, H.-L. Vibrational Modes of the Vinyl and Deuterated Vinyl Radicals. J. Phys. Chem. A 2009, 113, 8857-8870.

(62) Durig, J. R.; Johnston, S. A.; Moore, T. F.; Odom, J. D. Raman, infrared and NMR spectra and structure of divinylmethylborane. $J$. Mol. Struct. 1981, 72, 85-97. 
Table of Contents (TOC) artwork

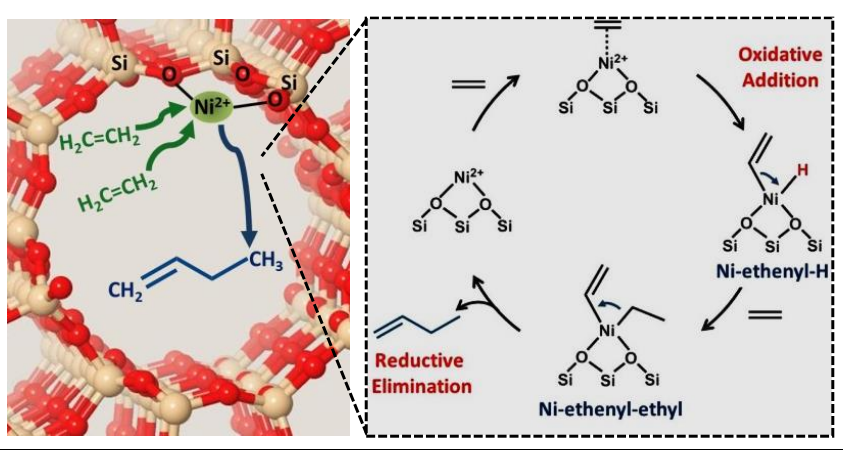

